\title{
Cooperation Of Indonesia - Iran In The Oil And Gas Energy Sector 2015-2017
}

\section{Asep Kamaluddin, Laode Muhammad Fathun, Utami Nadirah Rahladhani}

\section{Asep Kamaluddin}

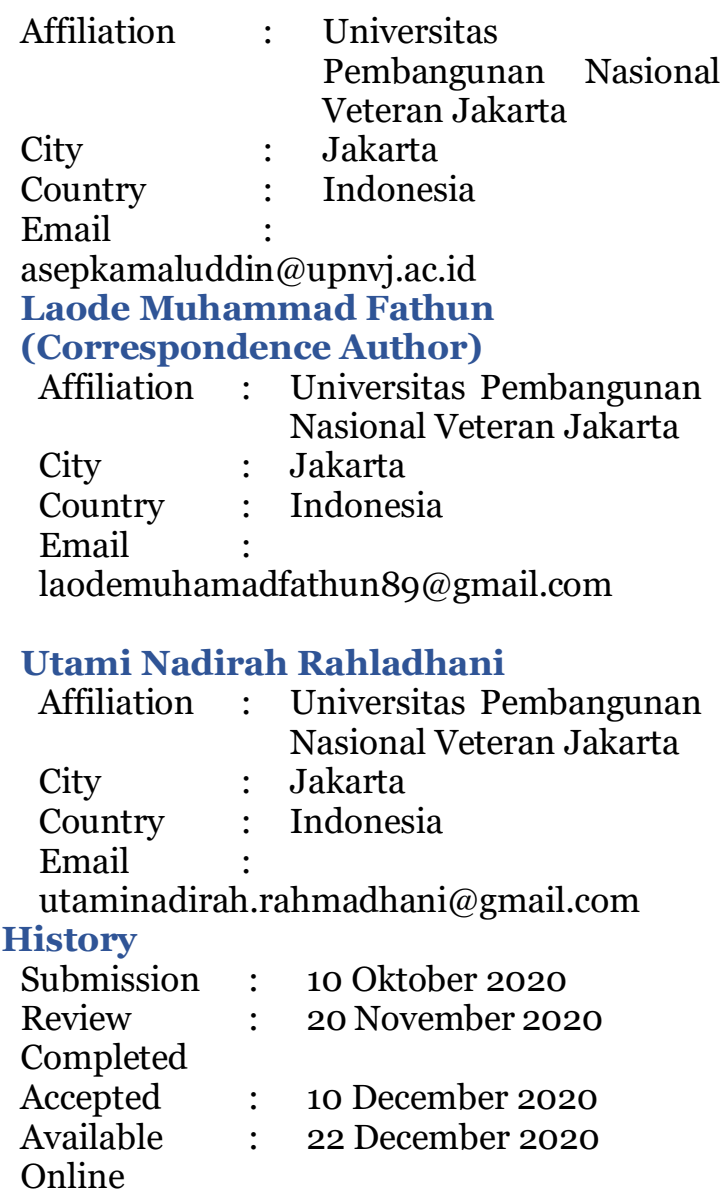

DOI :

10.51413/jisea.Vol1.Iss2.2020.194-210

Copyright

This is an open access article distributed under the term of the creative commons attribution 4.0 international licence

\begin{abstract}
This research is conducted to discuss about the Cooperation between Indonesia and Iran in oil and gas energy sector period 2015-2017. This research uses qualitative research method with descriptive approach. The purpose on this research is to explain to cooperation between Indonesia and Iran in oil and gas energy sector. This research also uses bilateral cooperation theory, national interest concept, and energy security concept. Result from this research, the cooperation between Indonesian and Iran in oil and gas energy sector in the period of 2015-2017, the first is Purchasing of Liquified Petroleum Gas (LPG) and Crude Oil form Iran with Competitive Price, second, Oil Refinery Development located in Situbondo (East Java). With Impact of this cooperation for Indonesia can to building economic security in energy sector. Then in this research, it is also known that the cooperation between Indonesia and Iran in the energy sector will continue even in the very important.
\end{abstract}

Key Words: Cooperation, Indonesia, Iran, Oil and Gas, Energy Security

\section{Cite this article :}

Kamaluddin, A., Fathun, L. M., \& Rahladhani, U. N. (2020). Cooperation Of Indonesia - Iran In The Oil And Gas Energy Sector 2015-2017. Journal of International Studies on Energy Affairs, 1(2), 194-210. https://doi.org/10.51413/jisea.Vol1.Iss2.2020.194210 


\section{INTRODUCTION}

Indonesia as to developing country has toned energy. Energy is very important for economic development. Energy can build the country's economy where the energy industry itself as a commodity to increase foreign exchange and provide a place of employment for the people in the country. Energy is also one of the drivers for carrying out the activities of a country so that the The more developed a country, the more it needs a very large energy supply. In Indonesia, energy commonly used to carry out activities usually uses oil and gas. Non-renewable energy resources such as oil and gas are increasingly scarce to obtain due to the increasing use in society and industry, making Indonesia's energy supply in a weakened position.

The potential of oil owned by Indonesia for now is not yet significant oil refineries. Indonesia are also still not well managed, moreover the development of the oil and gas sector in Indonesia at this time also still has to be improved considering the increasing number of oil and gas needs in Indonesia every day but not commensurate with the amount available in the country. In addition, oil and gas production and oil and gas reserves in Indonesia are also decreasing.

Data from the last 4 years shows that the number of production and also Indonesia's oil and gas reserves has decreased every year, starting from 2011-2014 Indonesia is only able to produce around 789 thousand barrels of oil per day and only 8,217 thousand barrels per day for natural gas. Indonesia has 3,624 barrels of reserves for oil and 100.3 TCF for natural gas (Directorate General of Oil and Gas ESDM, 2016).

The decline in production and also the reduction in oil and gas reserves in Indonesia in the 2011-2014, is more due to the age of Indonesia's old oil fields, and technical problems such as pipe leaks, equipment damage, and other natural disturbances. Seeing the number of oil and gas reserves that Indonesia has increasingly depleted and the decline in oil and gas production at that time, making Indonesia have to secure oil and gas reserves in the future cooperation with other countries is one effective way to overcome the problems being experienced by Indonesia at this time. In this oil and gas sector cooperation Indonesia sees Iran as a partner country worthy of cooperation, so far the relations between the two 
countries are running well, Indonesia and Iran are two countries that have the potential and capacity to complement each other, Indonesia's high growth with a large population clearly requires a high energy supply too. Iran as one of the largest oil and gas producers in the world is able to fill it.

In the energy sector, Iran is one of the countries with high reserves, Iran is the country with the fourth largest crude oil reserves in the world and the second largest natural gas reserves in the world. Iran is also among the top 10 world oil producers and the top 5 natural gas producers. Iran produces nearly 3.4 million barrels of oil per day and 5.7 trillion cubic feet of dry natural gas (ESDM, 2016). In January 2015 excavated in Iran, Iran proved to have around 158 billion barrels of oil reserves, representing nearly $10 \%$ world crude oil reserves and $13 \%$ reserves owned by OPEC (Organization of Petroleum Exporting Countries).

About 70\% of Iran's crude oil reserves are on land and the rest are offshore, most of which are in the Persian Gulf, Iran has also proven that it has around 500 million barrels of oil reserves, mostly offshore in the Caspian Sea. Whereas Iran's natural gas supplies $14.6 \%$ of the world's total needs until 2000, only one level below the Bahrain state (ESDM, 2016). Iran has also been actively involved in the OPEC (Organization of Petroleum Exporting Countries) along with Saudi Arabia, Kuwait, Iraq, Venezuela, Qatar, Libya, the United Arab Emirates, Nigeria, Ecuador and Gabon to discuss the oil products owned by their country. Based on the background that has been explained, the formulation of the problem to be discussed by the author in this study is: What are the forms of Indonesia-Iran Cooperation in the Oil and Gas Energy Sector for the period 2015-2017? With the cooperation between Indonesia and Iran, can to build economic interest for increase to energy security sector.

\section{METHOD}

This study uses qualitative research. Qualitative research can be defined as an intuitive and systematic research technique to help a researcher produce knowledge in an efficient and coherent way (Bakri, 2016). Qualitative research traditions that are often used include: Phenomenology Studies, Participatory Observation Studies-Symbolic Interactionalism, Ethnometodelogy Studies, Ethnographic Studies, 
Studies to find Grounded theories or commonly known as Gounded Research, Life History Studies, Hermeneutic Studies, Analysis Studies or Content Analysis , and Case Study. (Bungin, 2012)

Then the focus of this research is to describe and analysis the forms of bilateral cooperation in the oil and gas energy sector carried out between Indonesia and Iran which aims to achieve energy security. The type of research used in this study is descriptive research, which can later be used to describe social phenomena namely cooperation in the oil and gas sector carried out between Indonesia and Iran in detail. Which includes the form of cooperation, forms of development, management, benefits, and the results obtained from the realization of cooperation that has been carried out between Indonesia and Iran in the oil and gas energy sector for the period 2015-2017.

Data collection techniques used by the authors in this study were interviews and library research. The technique used is to conduct interview to Ministry of Energy and Mineral Resources, Directorate General of Oil and Gas, Ministry Foreign Affair, Directorate General Asia Pacific and Africa.with sources related to research. And library research by collecting data by examining a number of literature related to the problems being discussed, both in the form of books, journals, documents, magazines, newspapers etc.

\section{THEORETICAL FRAMEWORK}

\section{Bilateral Cooperation and National Interests}

Every country cannot stand alone to meet its needs so some countries form a partnership with other countries. According to K.J Holsti (1964), cooperation is: a. Relations between one country and another on the basis of mutual trust and meeting to produce something that is then promoted and reaches an agreement. $b$. The views or expectations of a country that policies decided by other countries will help the country to achieve other interests and values. c. Approval or certain problems between two or more countries in order to utilize equality of interests or exchange interest. d. Transactions between countries to fulfill their agreement. 
Every country in the international world has mutual relations and cooperates between countries to meet the same needs, benefits and goals with each other in terms of politics, economy, social, environment, culture and security. Cooperation between countries generally exists between two or more countries that have their respective regional and non-regional interests. Inter-state cooperation carried out bilaterally only involves two countries as partners in cooperation with interests and goals to build political, economic, social, environmental, cultural and security (Holsti, 1964). In international relations in liberal perspective, many countries collaborate bilaterally and are not based on geographical location, but often the cooperation carried out always tends to have economic and cultural similarities. Bilateral cooperation usually only involves private companies or industries.

In conducting cooperation, each country has national interests that must be achieved. In general, national interests can be explained as fundamental goals and final determinants that direct decision makers from a country in formulating their foreign policy, and the national interests of a country are typically elements that shape the needs of the most vital countries such as defense, security, military and economic welfare (Parwita, 2005).

National interests can also be as a direction for a country to be able to take a decision and also determine actions to establish cooperation with other countries. The fact that all countries must pursue their own national interests means that the state and other governments will never be fully expected, all international agreements are temporary and conditional on the basis of the country's desire to comply. All countries must be prepared to sacrifice all aspects to achieve their national interests (Sorensen, 2009). This concept to use explain to cooperation between Indonesia and Iran for increase national interest to build energy security.

\section{Concept of Energy Security}

Energy security is a concept where every country must be able to defend itself and carry out development by prioritizing security and the availability of adequate energy reserves at affordable prices, both oil and other types of energy (Yergin, 2006). Energy is managed based on principles of benefit, rationality, fair efficiency, increased value added, 
sustainability, community welfare, preservation of environmental functions, national resilience, and integration by prioritizing national capabilities (Yergin, 2006).

Energy security is related to the availability of energy in the long run, especially related to the time to supply energy in accordance with economic development and sustainable environmental needs. Energy security focuses on the ability of energy systems to compensate for demand and supply, the lack of energy security can have a negative impact on economic activities associated with prices that are not competitive or too volatile. (Agency, What Is Energy Security, 2017)

The concept of Energy Security (Energy Security) must cover several aspects. The first aspect is that there is a threat to Energy Security from political, economic, technical, psychological and environmental threats. The second aspect when viewed from the Security definition includes the price element and impacts on the state, where the price element can influence the uncontrolled fluctuations in an energy source and impact instability in a country's condition. The third aspect is the price of an Energy has a very large influence on the availability of funds and capital to invest in the development and exploration of energy resources. The availability of funds is a very important factor in maintaining the amount of demand for energy resources (Farid, 2015).

The fourth aspect is to manage energy resources by diversifying energy sources. The fifth aspect is to find new energy resources within the region aimed at reducing dependence on energy-producing countries (Farid, 2015). To truly ensure the energy security of a country, the country must do a number of things. First, the state must be able to estimate the amount of loss if the supply of energy sources is disrupted and prepare a number of solutions to the problem. The solution is by rationing and hoarding. Carakedua, guarantees supply from foreign suppliers. The third way is the state guarantees energy security. The three methods can be carried out provided that the state really has abundant reserves of energy resources and has not been explored as a whole (Farid, 2015).

Energy security is one of the international problems and is one part of the foreign policy of countries in the world. Energy sources in the form of oil, natural gas and coal are not only considered as an important part of the 
growth of the national economy and international market products, but have very strategic values in national and international political security interests. Based on these conditions, it is oriented to the importance of cooperation between industrial countries and countries that produce energy sources. Collaboration carried out by industrial countries with countries that produce energy sources is the activity of collaborating on trade in energy resources, cooperation activities in finding new energy sources, exploration and collaborative activities in securing energy sources. In relations to the case of Iran-Indonesia energy cooperation, the energy security concept is useful to analyse the characteristics of their relationship for economic development in energy sector stability.

\section{DISCUSSION}

\section{Indonesia's Oil and Gas Potential}

Indonesia relies on petroleum, natural gas and coal as sources of energy, industrial raw materials, and state income. But as a state income, this sector in the last 5 years has continued to decline. The potential for oil and gas in Indonesia is still quite large, but in remote areas, deep sea, wells and also old oil fields, which are mostly located in eastern Indonesia, have not been explored further. Petroleum production in Indonesia is primarily intended for domestic consumption but in recent years the number of existing production has decreased. In 2014, oil production was only around 789 thousand bpd or decreased to 96\% compared to 2013 at 824 thousand bpd. Since 2010, d. 2014 decreased production by an average of about $4.41 \%$ per year.

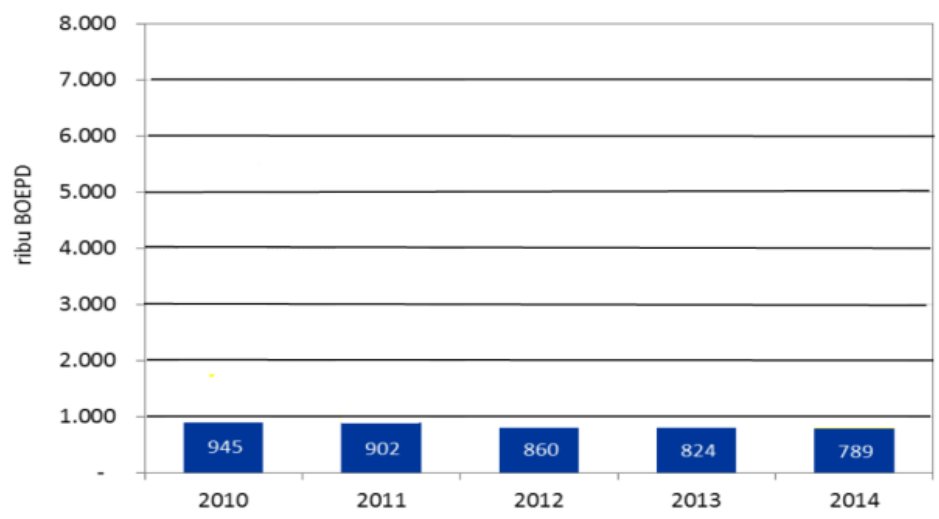

Figure 1 Petroleum Production 2010-2014 Source : DITJEN Migas ESDM 
The decline in production can occur more due to the aging of Indonesia's oil fields, and technical obstacles such as unplanned shutdown, pipeline leakage, equipment damage, subsurface constraints and natural disturbances. In addition to decreasing production of petroleum reserves in Indonesia it is now difficult to find more, data from 2010-2014 total proven reserves owned by Indonesia amounted to 3,624.5 MMSTB. This reserve has decreased compared to the previous year of 7.305 billion barrels (Directorate General of Oil and Gas ESDM). One of the things that causes the lack of Indonesia's petroleum reserves that exist today is that no new proven reserves have been found and no exploration has been carried out on wells or oil fields in Indonesia.

The production and reserves of petroleum in Indonesia have decreased but its consumption has actually increased not proportional to the production and reserves it has because this is due to the growing population, the increase in the middle class population, and rapid economic growth which has resulted in rapid consumption of petroleum. demand for fuel continues to increase.

Table 1 of Indonesian Petroleum Consumption 2010-2015:

\begin{tabular}{cr|rrrrr} 
Unit & 2010 & 2011 & 2012 & 2013 & 2014 & 2015 \\
Barel per day(Bpd) & 1,402 & 1,5891 & 1,631 & 1,643 & 1,676 & 1,628
\end{tabular}

Source: BP Statistical Review of World Energy 2015

The high consumption of petroleum is also influenced by activities in the community that use oil relatively. This increase in consumption occurs in Indonesia, especially in densely populated islands. Until now, Java Island is the region with the most oil and gas consumption due to its large population, which requires a large amount of oil and gas consumption.

Similar to petroleum, the condition of natural gas in Indonesia is also not significant, because the production and utilization of natural gas in Indonesia in the last 5 years continues to decline, natural gas production is only 8,130.00 MMSCFD, and for its utilization of 7,364.13 MMSCFD has decreased by 140 MMSCFD from the previous year (Directorate General of Oil and Gas ESDM). The decline in natural gas production 
occurred because no new natural gas reserves were found and the development of gas fields in Indonesia has not yet been developed due to the difficulty of buying gas at low prices and often absorption from gas purchases that are not optimal due to global economic conditions. In addition, Indonesia's natural gas reserves are also getting smaller, currently proven gas reserves are only around 100.3 TCF with a potential of 49.0 TCF and are estimated to only be able to survive for 34 years.

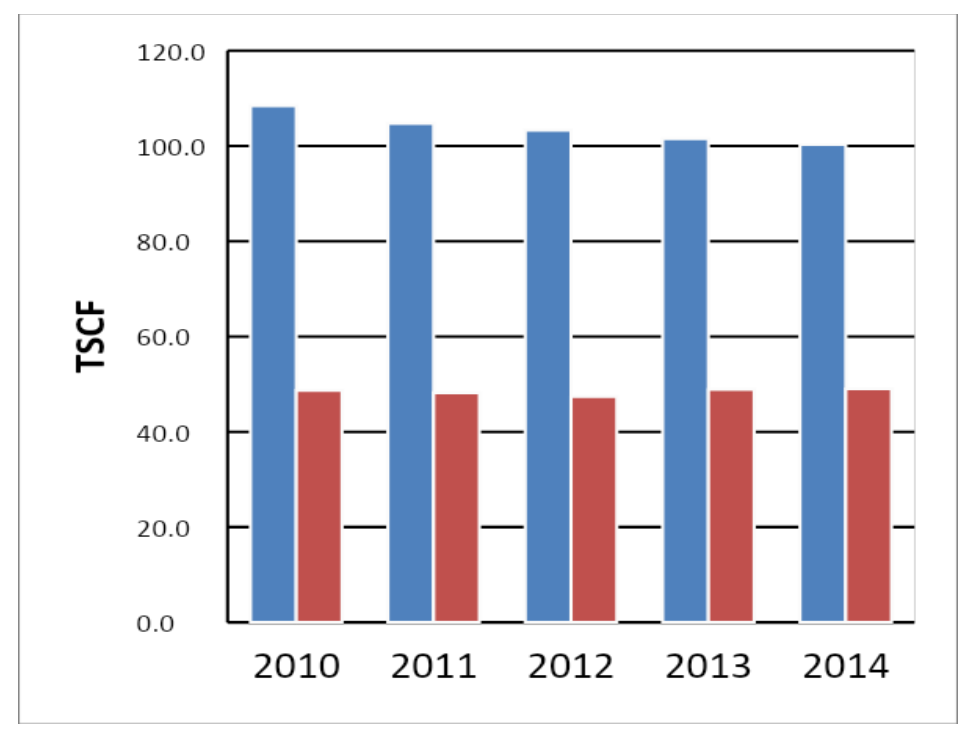

Figure 2 Indonesia Natural Gas Reserve Source: Ditjen Migas ESDM

If no proven reserves are found, it is feared that natural gas reserves in Indonesia today will no longer be able to meet domestic needs. With such natural gas reserves, the level of natural gas consumption in Indonesia in the past 5 years falls into the category The low one. This is caused by the use of gas among the community not as much as the use of oil. Indonesia is listed as one of the countries with the lowest amount of natural gas consumption. As from 2010-2015, Indonesia consumed natural gas with only 39.7 billion. The amount is still included in a reasonable amount. 
Table 2 of Consumption of Indonesian Natural Gas 2010-2015

$\begin{array}{lllllll}\text { Unit } & 2010 & 2011 & 2012 & 2013 & 2014 & 2015 \\ \text { Billion } & 43.4 & 42,1 & 42,2 & 36,5 & 38,4 & 39,7\end{array}$

Source: BP Statistical Review of World Energy 2015

Indonesia, despite being said to have high potentials, in recent periods has had to face several obstacles and challenges that are quite complex and have an impact on Indonesia's energy security in the future. Among these obstacles are the drastic decline in oil and gas production in Indonesia, the very low oil and gas energy use, oil and gas energy access is still limited, dependence on imports, and energy prices that are not competitive, and energy subsidies are still very high.

The Indonesian government has made various efforts to increase oil and gas reserves and production, the Indonesian government has not stopped there, in recent years the issue of energy security is one of the issues that has become a challenge in carrying out Indonesia's foreign political activities (Natural, 2014, p. 188 ) In Indonesia, the government only relies on Pertamina in reducing oil and gas reserves, so far there has been no strategic step prepared to increase the reserves, the provision of oil and gas reserves in the long term cannot be separated from government participation (Indirasardjana, 2014, p. 218). In terms of energy there are several facts that require the Indonesian government to implement policies that are in accordance with the current state of the oil and gas energy sector in Indonesia.

The Indonesian government to take various policy steps and strategies for energy security. The purpose is to ensure the availability and adequacy of energy for the community at affordable prices (Alami, 2014, p. 189). One of the government's policies in achieving this goal is to establish cooperation with countries that have high oil and gas reserves and also have good bilateral relations with the Indonesian state. In accordance with the principle of being free to actively cooperate in the energy sector, the Indonesian government is now widely actively involved in various international energy cooperation frameworks, both bilateral, multilateral and regional cooperation. 
Then in the period of 2016 to 2017 the Indonesian government has explored cooperation in the oil and gas energy sector with partner countries namely Iran. In recent years Iran has proven to have high oil and gas reserves, Iran also ranks the top of the country with the support of the largest subsidies for domestic oil consumption, Iran is also the world's energy superpower, and ranks second in OPEC after the Saudi Arabia. With GDP of more than US \$ 12 thousand and a population of only around 77 million, Iran controls the world's largest gas reserves with a total of more than 34 trillion cubic meters and oil reserves ranked third in the world (Indirasardjana, 2014, p. 35). The success of Iran in producing oil and gas every year believes that the Indonesian government can cooperate with Iran, the aim of this policy is to achieve Indonesia's national interest, namely securing Indonesia's energy in the future.

\section{Cooperation between Indonesia and Iran}

President Joko Widodo paid a visit to Iran to realize a joint economic cooperation committee with Iran, the Joint Committee of Iran and Indonesia was divided into four committees namely: financial and banking committees, industry, trade and investment committees and energy and work committees Collaboration between Indonesia and Iran has also been established in the oil and gas energy sector. Usually in the context of cooperation in the field of energy there must be national interests to be achieved, one of which is to guarantee national energy security.

There are several fields that are the focus of cooperation between Indonesia and Iran, these fields are: upstream oil and gas cooperation, trade in oil and gas products, gas projects, oil processing, petrochemicals, oil and gas supporting industries, to increasing human resource capacity in the oil and gas sector. During this time, the cooperative relations between Indonesia and Iran have indeed gone well, starting from shortterm cooperation in the form of services and trade, which after that began to be developed in the medium and long term. Cooperation between Iran and Indonesia will be deeper in the oil and gas sector with the establishment of cooperation between Pertamina and the National Iranian Oil Company (NIOC). 


\section{Cooperation between Indonesia and Iran And Impact to Oil and}

\section{Gas Energy Sector}

This collaboration is in the form of Government to Government ( $\mathrm{G}$ to $\mathrm{G}$ ) as a means of diplomacy and also of course the realization of bilateral cooperation as well as supporting the cooperation of Business to Business (B to B) carried out by the state-owned enterprises of the two countries, both related to investment and trade. This collaboration began when the Indonesian government initiated a $G$ to $G$ meeting with Iran in the 1st Indonesian-Iranian Joint Technical Committee on Oil and Gas on February 24, 2016 in the city of Bogor. The meeting resulted in the signing of a Memorandum of Understanding between the Ministry of Energy and Mineral Resources (ESDM) and the Ministry of Petroleum of the Islamic Republic of Iran regarding cooperation in the upstream and downstream fields of oil, gas, refineries and petrochemicals. The logic of cooperation use to liberal perspectives. The cooperation use to you and me another profitable. Cooperation between Indonesia and Ira for increase national interest for economic development.

Both countries' oil and gas cooperation is carried out both upstream and downstream. On the upstream side related to the efforts of the Government of Indonesia through PT. Pertamina to be able to manage and also explore oil and gas fields in Iran, namely Ab-Teymor and Mansouri, while on the downstream side is the realization of LPG and Cruide Oil purchases, as well as plans to build oil refineries in the Situbondo area (East Java) with oil supplies originating from Iran.

\section{Purchasing Liquefied Petroleum Gas (LPG)}

One of the cooperation agreements between Indonesia and Iran is the purchase of LPG. In the purchase of LPG, from Iran, it is willing to sell its LPG supply to Indonesia and the Indonesian side can produce it at a relatively cheap price. It aims to support reserves and also increase gas production in Indonesia. In this form of cooperation, PT. Pertamina along with National Iranian Oil Company (NIOC) was entrusted by the Indonesian government to coordinate this activity. In 2016, the purchase of this LPG was agreed to be 600,00o Metric Ton (MT), of which 2 LPG cargoes loaded with 44,000 MT each were sent and traveled around 13 days using verylargegascarrier vessels to the Situbondo refinery. Then on 
the next purchase, PT. Pertamina and NIOC signed a Sales and Purchase Agreement (SPA) related to the continued purchase of LPG amounting to 528,000 MT in 2017, with the provisions of 8 cargoes which are part of the agreement between the two countries and 4 other cargoes to be sent according to Indonesia's domestic supply needs. The shipment of 1 initial cargo loaded with 44,000 MT LPG arrived in Situbondo at the beginning of 2017. Then for this type of LPG provided by Iran this type of Propane and Butane is in accordance with the type of LPG that is used daily in Indonesia.

The value of transactions made in purchasing LPG is 220 USD equivalent to 3 trillion rupiah for a total of 12 cargoes per year. With such a price, it can be said that the Indonesian government can do price efficiency, because from the purchase of LPG directly to Iran the Indonesian government gets a competitive price with a value of one year savings of 10 million USD (Martin Hasugian, 2017). In buying LPG from Iran, it can be seen that while exploring the cooperation of the Iranians to give a very good response, the prices that tend to be cheaper given by Iran make Indonesia establish this oil and gas collaboration with more confidence, because of the intimacy between the two, especially during each had become OPEC member countries. In addition, the purchase of LPG at competitive prices has made the Indonesian government able to carry out price efficiency.

\section{Purchasing Crude Oil (Crude Oil)}

In the form of further cooperation, the Indonesian and Iranian parties have agreed to purchase CrudeOil from Iran for Indonesia at a cheap price. This CrudeOil purchase is done in two stages. The first phase was carried out on February 2, 2016 and the amount of crude oil purchases amounted to 950 barrels, in the first phase of the purchase it was intended to fill the lack of oil reserves in the Cilacap Refinery. Then for the second stage carried out on February 4, 2017, the total amount of crude oil purchases in the second phase is also 950 barrels intended to fill oil reserves at the Situbondo oil refinery and also to meet oil needs at oil bases in Indonesia (Martin Hasugian, 2017). The shipment of crude oil is also loaded on FOB Kharg Island and from Iran, it is estimated that this oil reserve will last for the next 3 to 4 years. 
In this form of cooperation, Indonesia has benefited from the supply of crude oil from Iran so that the existing reserves in Indonesia have increased so that Indonesia is able to meet the needs and consumption of oil in the country, besides cheap prices imposed by Iran can make Indonesia do price efficiency in a purchase transaction, thus Indonesia is also able to save state cash. The collaboration between Indonesia and Iran is in accordance with the concept of energy security which was proposed by Daniel Yergin (2006). Where every country is required to be able to meet domestic energy reserves at a price that is also competitive so that it can provide benefits for the country in meeting energy needs without having to spend expensive costs to buy them (Yergin, 2006).

\section{Construction of Oil Refineries}

The oil refineries in Indonesia are indeed very old, the development of oil refineries in Indonesia has not progressed since the last RU IV Balongan refinery. However, the Indonesian government continues to strive for the availability of oil to remain available to meet the needs of the Indonesian people. In this collaboration between Indonesia and Iran, the two governments have agreed to build a private oil refinery in Indonesia to be able to produce oil in their own country.

Based on effort to realize energy sovereignty through the supply of processed oil, this cooperation in the oil and gas sector between Indonesia and Iran has a plan to build an Indonesian oil refinery located in Situbondo (East Java). The construction of this oil refinery is carried out through an Iranian oil company, Naftiran Intertrade Company (NICO), which is a subsidiary of NIOC which has been appointed by NIOC to cooperate with PT. Kilanindo Golden Star (KGS) plans to build an oil refinery in Situbondo with a land area of 35 ha and of course with a supply of crude oil from Iran in the amount of 150,000 barrels per day in the period for the next 15-20 years. The contract value of the construction of this oil refinery is approximately US $\$ 5$ billion.

In addition, Iran has also prepared a Feasibility Study to determine what type of oil is suitable for use at the Situbondo oil refinery. The need for domestic fuel directly requires the availability of sufficient oil and gas processing facilities. Both installed capacity and production capacity. With the construction of this oil refinery it is a big advantage for Indonesia 
to invest in oil processing. Given that the demand for fuel in Indonesia is quite high and Indonesia has a goal of achieving energy security, then Indonesia should need to grow the domestic refinery industry. Then the cooperation in the construction of this Situbondo refinery Indonesia has benefited in securing national fuel stock, and also can reduce dependence on fuel imports because oil can be processed domestically by using work programs that are in line with refinery capacity. professional employment or refinery operations, absorb local labor in the construction of refineries, and can also increase the economy and increase regional income in the vicinity.

\section{CONCLUSION}

Cooperation between Indonesia and Iran in the oil and gas energy sector for the period 2015-2017 is mutual benefit. It can be concluded that the first form of cooperation between Indonesia and Iran is the purchase of LPG and Cruide Oil to supply domestic needs in Indonesia, second is the construction of oil refineries in the Situbondo area (East Java) with oil supplies from Iran, and third is Management Iran's oil and gas fields are $\mathrm{Ab}$-Teymour and Mansouri. In carrying out this collaboration, Indonesia collaborates with a domestic company, PT. Pertamina while Iran cooperates with the National Iranian Oil Company (NIOC) to facilitate the cooperation. And in implementing cooperation, this collaboration is considered very beneficial for Indonesia in increasing oil and gas production and also achieving national interests to meet the security of the domestic energy sector.

In undergoing this partnership, Indonesia has many advantages including that Indonesia can buy LPG from Iran at affordable prices so that the Indonesian government can make price efficiency and save foreign exchange. In addition to the construction of an oil refinery in Situbondo (East Java), Then the management of the Iranian oil and gas field, AbTeymour and Mansouri, brings benefits to the Indonesian oil and gas company Pertamina, with this activity being able to increase Pertamina's experience and competition abroad and also increasing the credibility of the company in the eyes of international sources.

With this collaboration between Indonesia and Iran, Indonesia is able to increase its oil and gas production, in accordance with the period studied, 
namely 2015-2017, throughout 2015, the total oil and gas production in Indonesia reached 2,228 thousand barrels, then in 2016, reached 2,249 thousand barrels, and in 2017 reached 2,162 thousand barrels. This number increased compared to the previous year which only amounted to 789 thousand barrels. Then after implementing cooperation in the oil and gas energy sector, between Indonesia and Iran.

\section{REFERENCES}

Agency, I. E. (2008). Energy Policy Review of Indonesia. United Kingdom:Organization for Economic and Coperation Development.

Alami, A. N. (2014). Politik Luar Negri Indoneia dan Isu Keamanan Energi. Lembaga Ilmu Pengetahuan Indonesia.

Bakri, U. S. (2016). Metode Penelitian Hubungan Internasional. Yogyakarta: Pustaka Pelajar.

Bungin, B. (2012). Metode Penelitian Kualitatif Analisis Metodelogis Ke Arah Ragam Varian Kontemporer. Jakarta: PT Raja Grafindo Persada.

ESDM, K. (2015). Rencana Strategis Migas 2015-2019. Jakarta: Direktorat Jendral Minyak dan Gas Bumi Kementerian ESDM.

ESDM. (2016). Mewujudkan Nawacita "Era Baru Pengelolaan Infrastruktur Migas". Jakarta: Direktorat Jendral Migas Kementerian ESDM RI.

ESDM. (2016). Profile Energi Iran . Iran

Holsti, K. (1964). The Concept of Power in the Study of International Relations. Background, 7: 179-194.

Indirasardjana, P. (2014). 2020 Indonesia dalam Bencana Krisis Minyak nasional . Jakarta: PT. Gramedia Pustaka Utama.

Indrasardjana, P. (2014). Minyak Untuk Presiden, Jakarta, PT.Gramedia Jakarta. 
Kementerian Energi dan Sumberdaya Mineral, Data Statistik Minyak dan Gas Bumi, 2016

Kementerian Energi dan Sumberdaya Mineral, Mewujudkan Nawacita "Era Baru Pengelolaan Infrastruktur Migas"

Parwita, A. A. (2005). Pengantar Ilmu Hubungan Internasional. Bandung: PT Remaja Rosdakarya.

Pujayanti, A. (2012). Sanksi Ekonomi terhadap Iran dan Dampak Internasionalnya. Info Singkat Hubungan Internasional, 2.

Sinaga, S. B. (2017). Kendala Kemajuan Industri Hulu Migas. 1.

Sorensen, R. J. (2009). Pengantar Studi Hubungan Internasional. Yogyakarta: Pustaka Pelajar.

Yergin, D. (2006). Ensuring Energy Security. Foreign Affair, 69-71 